\title{
Characteristics of Common Turkisms in Albanian-Greek Dictionary in Folk Collection "Bëleta shqypëtare" of Thimi Mitko
}

\author{
Doc. Dr Lindita Xhanari (Latifi) \\ Dr. Helena Grillo
}

Doi:10.5901/mjss.2014.v5n3p627

Dr. Spartak Kadiu

\section{Abstract}

Turkish language has been one of the most important sources of vocabulary enrichment for Balkan languages in the course of five-century long Ottoman rule. All Balkan languages, more or less, have given and taken from each other. Influence in these languages has been of local character and limited only in border-area dialects. Contrary to these influences, Turkish borrowings have been spread in a uniform way in all Balkan languages, and a considerable number of them can even be defined as Balkan Turkish words". This is the fundamental right that encourages us to analyze in this work the common fund of Turkisms in Albanian-Greek Dictionary, accompanying the folk work "Bleta Shqyptare" (Albanian Bee) by Thimi Mitko.

Keywords: Albanian-Greek Dictionary, Turkish language, influence.

Several Balkan linguists use the term "orientalisms" for these borrowed words, offering as an argument their Persian and Arab origin of these works. In this article, same as in previous works, we prefer and choose to use the term "Turkisms" for two reasons:

First, Balkan peoples had direct contact with Ottoman population, not Arabs or Persians.

Second, all these words have been borrowed directly from Turkish language.

Sporadic examples of use of borrowed Turkish words in texts of different Balkan languages (Albanian, Bulgarian, Serbian, Croatian, Macedonian, Bosnian, Greek, Romanian) dated back to early XV century. Process of borrowings from Turkish language in these languages culminated in XIX century. Balkan people used Turkish language to communicate within the Ottoman Empire. Majority of Turkish lexis has not only fitted into Balkan languages, but has also turned into a natural component of general and regional language. Borrowings not only were accepted by languages spoken in the Balkans, but were also attached to literature, learned religious language, administrative papers and other written texts. Natural consequence of contact between different nations in the course of history is inter-action between their languages and cultures. The arrival of Ottomans in the Balkan, it was established a new state system, new culture, new religious belief. These new culture ruled for centuries. These novelties brought in a big change in social, economic, education and cultural fields in the entire Balkans. Religion and traditions introduced by Turks, i.e. life style presented by them was accepted by majority of Balkan countries. Even though Turkish language marked a mass embrace, it never reached the status of lingua fatica, because all Balkan people continued to use native languages in their daily life. (Filan\&Kerima, 2001) Status of Turkish language was completely different from status of other oriental languages, because Arab and Persian languages were limited in only some fields of life, such as belief, science and education, whereas Turkish was used in everyday life, as a language used in government institutions, trade and social life. An indicator of this influence is the big number of Turkish words entering the Balkan peoples' languages. The novelties introduced from Turkish culture also brought in new concepts that were not known in those areas at then period of time. Until then, there existed no words in native languages about those new concepts, therefore Turkish words and terminology was transferred in almost all Balkan languages. Beside, switch to a new lifestyle was accompanied with borrowing of Turkish words, which did not existed in those languages. In other words, Balkan peoples borrowed words that did not have equivalents in their languages. This situation consolidates the fact that borrowing process does not only depend on linguistic reasons, but also on extra linguistic reasons.

Nevertheless, borrowed Turkish elements, terms and a limited number of suffixes, despite a dense use in all Balkan languages, they have never been a threatening for failure of their essence. (Filan, 2001). The borrowings were adapted within the lexicon of each language that embraced them, and continued to live in that new system meeting the characteristics of the respective languages. Process of entrance of Turkish-Oriental borrowings, which lasted for about five centuries, is presented as a colourful panorama involving historical, cultural, ethnographic, literature and linguistic 
issues. This is not only a simple word and meaning borrowing. At first, Balkan languages due to their already known historical circumstances have borrowed unknown meanings and notions to them. Later on, these words have been accepted and started to be assimilated in mass, because of their dense use in social and administrative daily life. After being accepted, used and assimilated, Turkish-Oriental borrowings in Balkan languages started to be elaborated and enriched. This is a chain reaction that has continued for a long period of time. In this respect, naturally are raised the following questions:

\begin{abstract}
What is the level of acceptance and assimilation of these borrowings? What is the ratio of these borrowings from one language to the other and did they resist centuries in the same way in all Balkan languages? Does there exist a joint fund of borrowings from Turkish language? What are the characteristics of this fund? Which lexical fields include the common Balkan fund? What is the adaptation level of Turkish word forming suffixes with ways and types of Balkan languages word forming?
\end{abstract}

Despite efforts to present only the essence, the complexity of this issue cannot be addressed only with one work. Today, Turkisms take an important place in the lexicon of all Balkan languages. They consist of an undeniable reality and have considerably enriched the semantics of Balkan languages, especially with special stylistic values embraced in the course of the years. Despite semantic changes, in particular phonetic changes, the words that have entered the Balkan languages centuries ago were borrowed forms or meanings widely spread at the time. Indeed, words that were borrowed at first through spoken language were borrowed from Turkish dialects spoken in the Balkans. It was not a pure Turkish language and registers considerable differences from Istanbul Turkish language, on which was founded the literature Turkish language. Borrowings were in harmony with systems of language they embraced. They preserved the original forms, whereas those not in harmony were subject of phonetic and morphological changes. Every Balkan language counts in its lexical fund a relatively big number of Turkisms. Based on a study of dictionaries modern Balkan languages, the number of Turkish borrowed words is different for each different language. Even though, Ottoman influence was almost the same in all these countries, linguistic influence was not the same, and this did not depend only on linguistic characteristics of respective languages, but also on reasons that depend on expansion of Islam in Balkan peoples, as well as on countries that were invaded by Turkish Nomads, which until today exist in the form of national minorities in different parts of the Balkans. . The so far studies show that :

Albanian language has borrowed about 5000 words, where about 1800 of them are present in Modern Dictionary of the Albanian Language. Albanian and foreign scholars have been engaged in their study, such as E.Çabej (Çabej, 1975), A. Kostallari, (Kostallari, 1978) A. Krajni (Krajni, 1965), M.Samara (Samara, 1995), G. Meyer (Meyer, 1891), F. Miklosich (Miklosich, 1884, 1890), N. Boretzky (Boretzky, 1976). Nevertheless, greatest merit belongs to T. Dizdari (Dizdari, 2006), who left as a manuscript the wonderful work : Dictionary of Orientalisms, which today consists of most accurate and scientific research in the field of Turkish borrowings. The Dictionary consists of 4406 borrowings, which the author considers as direct borrowings from Turkish language. Together with words, even Turkish word forming suffixes have entered in the Albanian language. Borrowed suffixes from Turkish language that have become somehow productive in the Albanian language are as following:

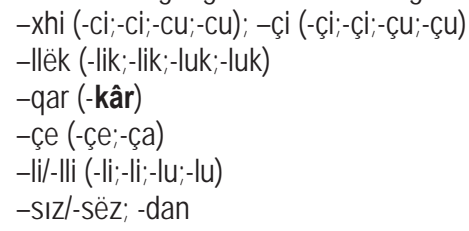

All these suffixes, despite their existence as phonetic versions in vocal harmony with Turkish language have entered the Albanian language by being adapted to its phonetic and grammatical structure.

Greek language, according to different scholars : Miklosiç, Gustav Meyer, Rouzevalle, Krumbacher, Kostantinos Kukkidis, Pavlos Georgidas, Evangelia Ahladi has borrowed about 4800 words. Triantaphyllides (Kazazis, 1969), in his observations, underlines that -ci suffix in Greek is used in the pejorative function. This author makes the same evaluation also for suffix - lik, which are also used in a pejorative way, except the cases were are used to refer to different official duties, but it is getting more and more an ironic and mocking meaning. Regarding suffix -li, he stresses that it is non-productive in the standard Greek language.

For years, these Turkisms have become object of study of scholars of these languages separately. They have been subject of study only in relation with Turkish language and never studies as a common element of Balkan languages. This is the fundamental right that encourages us to analyze in this work the common fund of Turkisms in 
Albanian-Greek Dictionary, accompanying the folk work "Bleta Shqyptare" (Albanian Bee) by Thimi Mitko.

This folk work was published in 1878. It contents a dictionary of about 1000 words, drafted to highlight foreign words in the text of the folk work.

Mitko has made efforts to determine the derivation of these words by marking their origin. Out of about 1000 words of this dictionary, 513 words are Turkisms. Despite a wrongdoing of the author or method used in compilation of the dictionary, it results that he has determined the Turkish source of Turkisms in a relatively correct way.

Following is the fund of these borrowings in alphabetical order :

adalet, ala, alaka, alamet, alem, alla, aman, amanet, ankran, arzuhall, asemin, asllan, ashkik, ashiku, ashiqare, at, azap, azat, bajrak, bajraktar, bajame, bardhak, bazerxhan, bast, bash, bahçe, beden, bedenat, behar, bekgu, beg, bela, belek, beqar, berber, berberhane, bereqet, bezdis, bilbil, bina, binish, bishbish, boja, borçxhi, borxh, bostan, bozuk, budalla, bugaszi, jatagan, xhep, çadër, çallma, çanak, çapërxhi, arixhi, çapraze, çarçaf, çardhak, çare, çarka, çati, çelengu, çerek, çezmë, çibuk, çifut, çipllak, çitjane, çizme, çoban, çollak, çorbë, dahil, daja, daim, dajlanë, daulle, dava, degdis, deli, derman, dert, deve, din, divan, divanhane, donama, dori, dovlet, duhan, duva, tyfek, dylber, dynja, dyqan, dyshek, eglenxhe, elçi, esmer, evlat, exhel, ezan, ezhdërha, fajde, fakir, fukara, felah, felek, fet, filxhan, fiqir, fodull, gaile, gairet, gale, garip, kaza, gazali, gazep, gonxhe, gjemenxhe, gjëmi, gjene, gjerdhan, gjezdis, gjoja, gjok, gjokësi, gjol, gjyç, gjyle, gjynah, gjyves, haber, hadet, hajdut, ajmali, hak, hakikat, hall, hallall, hallat, halldup, hamam, hallka, hambar, hani, hanko, hapsanë, haraç, haram, harap, harar, harbut, hasbin, haset, hasëm, hasi, hata, hatër, haxhet, hazne, hejbe, helaq, hem, heqim, hesap, hënxhir, hile, hilal, hudut, huqi, hyqëm, hyri, hyxhet, hysmeqar, ibliz, ibret, intikat, ilaç, ilaka, iman, imdat, inaet, inat, inqar, insaf, insan, inshallah, ispat, itilak, ixhat, izë, jahni, jallan, jara, jastëk, jatagan, javer, jediç, jeshil, jetim, jezit, jollëxhi, jorgan, jungar, jyrysh, kabah, kabil, kafas, kaftan, kahar, kahpe, kahreman, kahur, kail, kala, kallajxhi, kallauz, kallëp, kamare, kamatë, kapi, kara, karadag, karadyzen, karagrosh, karar, karaull, kasaba, kasabali, kasap, kasavet, kastilen, kavaz, kaza, kazaja, kazan, keçe, kezë, kërdis, kësëmet, këzdis, kimet, kllapodan, komshi, konak, kopil, kral, kujunxhi, kullandris, kullë, kulluk, kumbara, kurban, kurbet, kurdis, kusur, lale, lanet, lezet, lugat, llaf, magrur, makar, mall, mamur, mansup, maskara, mashalla, mavi, maxhar, medet, mehane, mejdan, melaiqe, memleqet, meqa, meram, merhaba, merxhan, mesele, meshrep, mexhelis, meze, mezil, mëhallë, mëhanë, miri, misër, misërli, misiri, muhabet, muhasere, muhtë, murat, murdar, mutaf, mymqyn, mynafik, mysafir, myshavere, nadan, nakar, nasiat, naze, nazik, nefes, neqes, niet, nihaiet, niqa, nishan, nizam, nofullzi, nur, oda, ogradis, ogur, okllai, orgjyn, orum, oxhak, palldëm, para, pazar, pegamber, pehriz, penxhere, perde, pervan, peshqesh, peshtamall, prangë, qafir, qamet, qar, qeder, qef, qehribar, qerem, qeros, qese, qira, qole, qorr, qoshe, qoshk, qylaf, qyrk, rae, rahmet, rajet, reçper, redif, rehat, rehvan, resmetar, ret, reze, rezeja, rixha, rixhal, riza, rumeli, rytbe, ryfet, sabah, sadik, sahat, sakat, sakaz, salltanat, samur, sanxhak, sarai, savat, sebep, sedef, sefer, sehir, selam, selamet, selvi, sene, sepet, serasqer, serdar, serek, serhat, sevda, sexhade, serma, simite, soj, sokak, spahi, stamboll, sulltan, sulltannevruz, surat, syrgjyn, syri, syrme, shah, shahin, shahir, shahit, shaka, shakaxhi, shall, shamata, shan, shandan, shart, sheboja, shehër, shejtan, sheriat, shhur, shilte, shishane, shura, shuret, shyqyr, tabak, tabake, tabor, tabut, taçe, taç, tain, takat, takdir, takëm, taksirat, talim, tambura, tapanxhë, tas, tasa, tavan, tavlla, taze, tehir, telef, tellall, tenxhere, tepsi, terezi, testemel, tevabi, top, topallti, tuja, turfanda, usta, vade, vali, vasiet, veliko, veqil, veresie, vesvese, vilaet, vukuf (vakuf), vuxhuh, xhaba, xhan, xhefa, xhelat, xhenet, xhephane, xhevahir, xheza, xhiger, xhihenem, xhika, xhinde, xhindeve, xhuxh, xhuma, xhuvap, xhymert, ylefe, yrnek, yzër, zahire, zallum, zaman, zambak, zanat, zandan, zap, zarar, ziafet, zile, zymbyl.

This corpus presents the following characteristics:

Majority of these borrowings, 323 words, are found in the Albanian and Greek Languages Dictionaries. Such are words:

alamet, alem, alla, aman, amanet, arzuhall, asemin, ashkik, ashiku, ashiqare, at, azat, bajrak, bajraktar, bardhak, bast, bash, bahçe, beden, behar, beg, bela, beqar, berber, bereqet, bilbil, bina, binish, boja, borçxhi, borxh, bostan, bozuk, budalla, jatagan, xhep, çadër, çanak, çapërxhi, çapraze, çarçaf, çardhak, çare, çarka, çati, çerek, çezmë, çibuk, çifut, çitjane, çizme, çoban, çorbë, daja, dajlanë, daulle, dava, deli, derman, dert, deve, din, divan, donama, dori, dovlet, duhan, duva, tyfek, dylber, dynja, dyqan, dyshek, eglenxhe, esmer, evlat, ezhdërha, fajde, fakir, fukara, filxhan, fiqir, fodull, gaile, gairet, kaza, gazep, gonxhe, gjemenxhe, gjëmi, gjerdhan, gjezdis, gjoja, gjok, gjol, gjyç, gjyle, gjynah, gjyves, haber, hadet, hajdut, ajmali, hak, hall, hallall, hallat, halldup, hamam, hallka, hambar, hani, hapsanë, haraç, haram, harap, harar, harbut, haset, hasëm, hata, hatër, hazne, hejbe, hem, hesap, hile, hyri, hysmeqar, ilaç, iman, inat, jahni, jastëk, jatagan, jeshil, jetim, jorgan, jungar, kabah, kafas, kaftan, kala, kallajxhi, kallauz, kallëp, kamatë, kara, karadyzen, karar, kasaba, kasap, kasavet, kastilen, kavaz, kaza, kazan, keçe, kërdis, kësëmet, kimet, komshi, konak, kopil, kullë, kumbara, kurban, kurbet, kurdis, kusur, lale, lanet, lezet, llaf, makar, mall, maskara, mashalla, mavi, medet, mehane, mejdan, meram, merxhan, mesele, meze, mëhallë, misër, muhabet, mutaf, mysafir, naze, nazik, niet, niqa, 
nishan, nizam, nur, oda, ogur, okllai, oxhak, palldëm, para, pazar, pehriz, penxhere, perde, peshqesh, peshtamall, qafir, qar, qeder, qef, qehribar, qeros, qese, qira, qole, qorr, qoshe, qoshk, qylaf, qyrk, rae, reçper, rehat, rehvan, reze, rixha, riza, rytbe, sabah, sahat, sakat, salltanat, sanxhak, sarai, sebep, sedef, sefer, sehir, selam, selamet, selvi, sepet, serasqer, serdar, sevda, sexhade, serma, simite, soj, sokak, spahi, stamboll, sulltan, surat, syrgjyn, shah, shahin, shahir, shahit, shaka, shakaxhi, shall, shamata, shandan, shart, sheboja, shejtan, shilte, shishane, shyqyr, tabak, tabake, tabor, tabut, taçe, takat, takëm, taksirat, tambura, tas, tavan, tavlla, taze, telef, tellall, tenxhere, tepsi, terezi, top, topallti, turfanda, usta, vali, vesvese, vilaet, vukuf (vakuf), xhaba, xhan, xhelat, xhenet, xhephane, xhevahir, xheza, xhihenem, xhinde, xhuxh, xhuma, xhuvap, xhymert, yrnek, zahire, zallum, zambak, zanat, zarar, ziafet, zile, zymbyl.

The semantic fields covered with words of this Dictionary are different. We can find:

Administrative and military terminology: kajmekam, vilajet, vergji, haraç, xhelep, padishah, xheza, vakëf, veqil, vali, tabor, tambur, sheriat, shehër, shahin, xhelat, syrgjyn, sulltan, spahi, serasqer, salltanat, sanxhak, mytesarif, qatip, hapsane, mexhelis, mejdan, memleqet, mëhallë, karar, kral, kasaba, kasabali, kamat, kahreman, kanun, llagap, allti, topanxhë, mill, kobure, vezme, kala, jatagan, insan, hyqëm, hapsanë, agzot, fishek, jeniçer, haraç, gjyç, gjyle, elçi, nishan, spahi, zaptije, silah, dovlet, dava, jatagan, beg, bajrak, bajraktar, batare, beden, jesir, beriha, karakoll, adalet, reçper, shart, xhephane, zap, zarar, vasijet, etc.

Religious Terminology: hoxhë, bajram, mevlud, din, nevruz, dua, gjynah, terikat, hajmali, hata, hyri, iman, inqar, jezit, kimet, kësmet, kurban, lanet, lugat, melaiqe, nijet, ogur, pejgamber, qamet, myezin, myfti, kalif, minare, vakëf, rahmet, taç, tespihe, selamet, sulltannevruz, shejtan, sheriat, xhenet, xhehenem, xhind, etj.

Social and household terminology: arkapi, mandall, muslluk, bodrum, karabina, hajat, bahçe, behar, amanet, bela, beqar, bereqet, bina, boja, borxh, bostan, xhep, çadër, çallma, çanak, çarçaf, buxhak, saraj, farashë, minder, ulluk, sepet, shilte, çardhak, çati, çezmë, çibuk, çitjane, çizme, çoban, çorbë, daulle, derman, dert, dyqan, dyshek, evlat, fajde, filxhan, fiqir, kaza, gonxhe, gjemi, gjerdhan, çengel, kandil, sënduk, haber, gjol, hak, hambar, haset, hasëm, hejbe, hesap, hile, ilaç, jahni, jara, jastëk, jallan, jetim, jorgan, kafas, kallauz, filxhan, matara, kallëp, karadyzen, kapi, komshi, kazan, kumbara, kurbet, kusur, lale, llaf, mall, mejhane, meze, muhabet, misër, mysafir, nishan, oda, okllai, pazar, para, penxhere, perde, peshqesh, peshtamall, qar, qeder, qehribar, qira, qoshe, qyrk, qylaf, reze, riza, sahat, sebep, sedef, sefer, selam, selvi, sene, sixhade, serma, simite, sokak, surat, shaka, shall, shamata, shandan, tabak, tabake, tabut, takat, takëm, tas, akçi, arapash, çyrek, gjevrek, kaçamak, japrak, jufka, kajmak, byrek, ermik, hoshmar, tavan, tavlla, tenxhere, tepsi, çervish, hasude, kaurma, samsa, zerde, shurup, sherbet, usta, vade, xhevahir, xhan, xhuma, xhuxh, xhevap, yrnek, zahire, zaman, zambak, zanat, zijafet, zile, zymbyl.

Words naming clothe wear and textile : allaxha, atllas, binish, burulluk, çallmë, jelek, çitjane, mitan, tallagan, xhep, xhoke, peshqir, mallotë, qefin, pashmagje, perçe, humai, fermele, çember, kundër, destemel, çorap, shirit, poture, xhanfes, xhaketë, fustan, futë etc.

Names of working tools : agërshak, burgji, çark, çekiç, çitar, çivi, çerçeve, kashai, makara, mengene, mamuz, gjyryk, hallat, qoster, qysqi, naxhake, teneqe, tezgjah tel, tebeshir, kësaç, mukava etc.

Names for materials :bakër, allçi, kallaj, bojë, fildish, farfuri, madem, serm, tunxh, xhevahir, zift, sedef, çelik, elmaz, xham, gjezap, inxhi, bilur, katran etc.

Terminology of education and culture : defter, bejte, kalem, kalemxhi, medrese, mejtep, myderriz, gazele, divan, qatip, qitap etc.

Terminology of plants : bizele, fasule, karpuz, salep, karafil, filzigen, patëllxhan, hashash, majdanoz, fëstëk, selvi, çiçibanoz, pelin, susak, shafran, menekshe, filiz, fidan, sefergjen, gonxhe, burnot, behare, limon, kajsi, shefteli, çam etc.

Words for physical characteristics of individual : qorr, topall, sollak, zaif, shishman, pis, abrash, ezmer, çyryk etc.

Words naming quality of the individual: ashik, babaxhan, çapkën, deli, dembel, hovarda, inatçi, çapaçul, beqar, fodull, asllan, beqar, budalla, çapërxhi, arixhi, çipllak, deli, esmer, fakir, fukara, fodull, gazep, hajdut, hain, harbut, hyzmeqar, jetim, jezit, kahreman, kasabali, kopil, qafir, qeros, qorr, sadik, usta, xhymert, etc.

Words naming professions : akçi, ahengxhi, arabaxhi, çirak, usta, nallban, salepçi, jorganxhi, esnaf, kundraxhi, hamall, kalldrëmxhi, pehlivan, sahatçi, bahçevan, fajdexhi, hallvaxhi, bozaxhi, bejtexhi, bakërxhi, fallxhi, dajrexhi, shair, shegert, sheqerxhi, xhelat, xherah, terzi, tellall, tyxhar, teneqexhi, xhamaxhi, tajë etc.

From the morphological point of view, the dictionary includes several Turkish suffixes. Majority of them are Turkish borrowings (Turkish root + Turkish suffix) borrowed as a whole, whereas the others are word formations of Albanian and Greek language speaker with elements of Turkish language (i.e. Turkish root + Turkish suffix ). The dictionary includes following word forming suffixes: 
-xhi (all the phonetic versions of this suffix in Turkish language, based on its vocal harmony in Turkish language: $\mathrm{Cl},-\mathrm{Ci},-\mathrm{Cu}, \mathrm{cü}$, in Albanian and Greek has entered in the version -ci/-xhi). This suffix is present in 64 words : çarkaxhi, baxhi, bakërxhi, barkaxhi, barnaxhi, bejtexhi, belaxhi, beledxhi, bojnaxhi, bostanxhi, buxhukxhi, qeraxhi, qiraxhi, qymyrxhi, çarkaxhi, daullexhi, devdexhi, fallxhi, çarkaxhi, djathaxhi, fesadxhi, fitmexhi, gajretxhi, gallataxhi, haberxhi, hadxhi, hallexhi, hallvaxhi, hamarxhi, haderxhi, hengxhi (ahengxhi), hesapxhi, jabanxhi, jallanxhi, jerdamxhi, jorganxhi, ilmnxhi, inxhi, kafaxhi, kafexhi, kaiarxhi, kallajxhi, kamatexhi, kazanxhi, kopallexhi, kuidxhi, kundraxhi, kuraxhi, llafexhi, magazexhi, mejhanexhi, mirazaxhi, mizilxhi, ojnaxhi, peshkaxhi, postaxhi, shamataxhi, sheqerxhi, toptendxhi, trapadxhi, valanitsedxhi, ylmedxhi, zahirdxhi.

-llëk (all the phonetic versions of this suffix in Turkish language, based on its vocal harmony in Turkish language: lık, -lik, -luk, lük, in Albanian and Greek has entered in the version -lık/-lëk. This suffix is present in 49 words: açikllëk, agallëk, axhamillëk, ajlëk, akllëk, akshillëk, alltillek, anakllëk, azganllëk, baballëk, bakallëk, batakçillëk, bejlëk, besllëk, bohçallëk, qefilëllëk, dyzhllëk, dynjallëk, dogrillëk, dxhahillëk, dxhamaxllëk, fukarallëk, ganillëk, hadxhillëk, harvallëk, harullëk, hasallëk, heqimllëk, horrllëk, iasakllëk, jeshillëk, kallaballëk, kapsllëk, karshillëk, katillëk, kerkllëk, kollaillëk, maskarallëk, meidanllëk, odxhakllëk, pazarllëk, pehlivanllëk, perizllëk, sertllëk, serafllëk, taraxhillëk, ustallëk, zabitllëk, zenginllëk.

-li (all the phonetic versions of this suffix in Turkish language, based on its vocal harmony in Turkish language: -II, -li, -lu, lü, in Albanian and Greek has entered in the version -li/-li. This suffix is present in 38 words: astahaneli, batalli, behaneli, bereqeti, bojnali, borxhli, qefli, demeli, dertli, dxhevapli, gairetli, hairli, hamalli, itibarli, kabahetli, kimeti, kyvetli, mahalleli, merakli, marifetli, nafakli, nami, myhyri, odxhaklli, pullali, sabërli, safali, serdari, sermali, sevapli, sertli, soili, sheqerli, shybeli, shykretli, takatli, turli, zehirli.

-çi (all the phonetic versions of this suffix in Turkish language, based on its vocal harmony in Turkish language: çı, -çi, -çu, çü,. This suffix is present in 8 words: barotçi, çerekçi, xhepçi, elçi, inaietçi, simitçi, tyfekçi, gjymrykçi.

-qar. This suffix comes from Persian source and has taken a very small place in Turkish-Oriental borrowings. In this dictionary, this suffix is present only in 7 words: amanetqar, gazepqar, gjynahqar, kabahetqar, hileqar, hyzmeqar, zahunqar.

3. Cases of borrowed verbs are rare. We can mention: degdis (degenmek), kërdis (kirmak), kullandris (kullanmak), kurdis (kurmak). These verbs have been borrowed without suffix of Turkish infinitive -mak/-mek. On the other side, other characteristics of these verbs, not only in Greek, but also in Albania, is the Greek aorist suffix -is.

4. Likewise, the dictionary includes some adverbs, conjunctions, and participles such as: aman, gjoja, gjene, hem, medet, nihajet, mymqyn.

The density of social and household terminology, as well as their morphological diversity shows that Turkisms in this period have started to bloom in these languages.

In this respect, we believe that "joint corpus borrowed by Turkish language enforces Balkan linguistic connections". (Reinkowski, 2001)

\section{References}

Banguoğlu, T. (1990). Türkçenin grameri, Ankara.

Boretzky, N. ( 1975). Der Türkische Einfluss auf das Albanische.

Boretzky, N. ( 1981). Sur la substitution des noms de profesion d'origine turque en albanais, Canier Balkanique, 2.

Çabej, E. (1975). For a chronological distribution of Turkish borrowings in Albanian language, SF ,1.

Demiraj, Sh.( 2004). Balkan Linguistics, Tirana.

Dizdari, T. ( 2005). Dictionary of Orientalisms, Tirana

Dictionary of Modern Albanian Language, Tirana, 1980.

Dictionary of Modern Albanian Language, Tirana, 1954.

Dictionary of synonymy of the Albanian language, Tirana, 2005.

Ismajili, R. (2000) Old texts , Peja.

Karaagaç, G. ( 2008). Türkçe verintiler Sozlügü, Ankara.

Kazazis, K. (1969). The status of Turkisms in the Present-Day Balkan Languages, Aspects of the Balkans. Continuity and Change, International Balkan Conference.

Kostallari, A.(1978). Entrance of Turkisms in Albanian language during XVII-XVIII centuries", Albanological studies, SSHF, Prishtina .

Krajni, A.(1965). Presence of Turkisims in Albanian language and efforts for their replacement, SF, 1.

Latifi, L. (2006). Turkish borrowings in Albanian language compared to other Balkan languages, Tirana.

Mandala, M., II Dittionario (1702) di F. M. Da Lecce e i turchismi nell'albanese (XVII-XVIII), Albanica 10

Meyer, G. (1891). Etymologisches Wörterbuch der albanische Sprache, Strasburg, 
Miklosich, F., Die Türkischen elemente in den südost-und osteuropaischen sprachen (V.I-II), Wien, 1884-1890.

Reinkowski, M. (2002), Zum Status der Turzismen in den sprachen südosteuropa.

Samara, M. (1995). Lexical-semantics of Turkisms in the Albanian Language, SF, 1-4.

Schütz, I.( 1986.)Traces of Medieval Turkish Languages in Modern Albanian language, International Seminar on Albanian language, literature and culture, Prishtina.

Vajzovič, H. (1999). Orijentalizmi u književnim dhelu- Lingvistička analiza, Sarajavo.

Xhuvani, A \& Çabej, E. (1962). Suffixes of the Albanian language, Tirana. 